DOI https://doi.org/10.18551/rjoas.2020-09.17

\title{
VOLATILITIES AND TRENDS OF GARLIC PRICE BEFORE AND ENTERING THE COVID-19 PANDEMIC IN NTT
}

\author{
Nendissa Doppy Roy, Olivana Tomycho, Herewila Kudji, Chamdra Santhy, \\ Siubelan Yakobus C.W.
}

Department of Agribusiness, Faculty of Agriculture, University of Nusa Cendana, Indonesia *E-mail: roynendissa@staf.undana.ac.id

\begin{abstract}
Disparities and price fluctuations in archipelagos regions such as NTT province can create inter-regional garlic price volatility. The distribution pattern of garlic trading in NTT is often hampered by limited marketing infrastructure, distribution network, and asymmetric information. This study measures the spillover volatility and the trend of garlic prices between regions in the NTT domestic market. This study uses time-series data onto garlic prices in Kupang City and Maumere City. Data period, price months from July 2016 to May 2020. The volatility analysis uses the ARCH / GARCH approach and the volatility spillover uses GARCH-BEKK. Analysis of price movements observed trends in price behavior before and entering the Covid-19 pandemic using graphical analysis. The study results concluded that the volatility of garlic prices in Kupang and Maumere is relatively low. Compared to the two regions, the price volatility in Maumereh is higher than in Kupang. The same thing happened to the level of price fluctuation in Maumere which was higher than in Kupang. Price volatility movements towards / away the two regions are not related to each other because these two regions receive garlic supplies outside NTT. Several factors can be the cause, including differences in marketing infrastructure, and different transportation networks between regions, the openness of price information. Therefore, transparency of price information and improvement of distribution networks to ensure the balance of supply and demand needs to be considered by all parties, especially regulators.
\end{abstract}

\section{KEY WORDS}

Volatility, garlic, COVID-19 pandemic, ARCH / GARCH, GARCH-BEKK.

Garlic commodities are one of the strategic food commodities that are easy to deal with price fluctuations in the domestic market. Until now, Indonesia has only been able to supply ten domestic garlic needs, while 90 percent must be imported (Kementerian Perdagangan, 2014). Indonesia is one of the largest garlic importing countries from China. The global economic crisis as a result of the Covid-19 pandemic has caused many countries to carry out state quarantine to impose city and state lockdowns. This condition is considered effective against preventing the spread of Covid-19, but from an economic perspective, it disrupts global business activities, thus affecting the price level of various world commodities, increasing unemployment and social unrest (Khan, et al 2020). The Chinese economy is closely related to all non-state economies in the world (Khan and Faisal, 2020). The real impact on the Covid-19 pandemic, among others, is that the supply of garlic for the domestic market from China has stopped temporarily, while Indonesia relies heavily on garlic from China. As a result, there is an opportunity for a supply shock and a demand shock, causing garlic prices to fluctuate and have an impact on high inflation as it is today. Low supply and high demand cause prices to increase and vice versa, resulting in price fluctuations (Gilbert and Morgan 2013; Caldara et al, 2019; Mortazavi et al, 2019; Geiger and Scharler, 2019). According to Tothova (2011), wide price movements away a short period of time symbolize high volatility. Prices change in response to a quick adjustment to a market situation. When these price movements are unpredictable, they lead to uncertainty. Food price volatility by FAO (2011) is seen as a price variation that fluctuates at any time, cannot be anticipated, which can lead to risk in decision making for economic actors (producers, consumers, and the government). 
One of the domestic markets that are currently experiencing a large supply and demand shock is the garlic market in East Nusa Tenggara (NTT) Province because its needs are always in deficit. Research from several sources has shown that the price of garlic in NTT will increase drastically if the supply is too late from Surabaya or other areas. antaranews.com reports (May 2019) that in April 2019 the price of garlic on the market in Kupang City (capital of NTT) was around IDR 20,000 per kg (Fardaniah 2019). The price began to move up to IDR. 60,000 - IDR.70,000 per kg entering the first week of May 2019. Then the price continued to rise to a peak of IDR. 90.00 per $\mathrm{kg}$ entering mid-May 2019, as reported by Media Indonesia on May 14, 2019 (Amalo, 2019). This happened because the supply of Surabaya was hampered. Due to the Covid-19 outbreak, the price of white baching in NTT has shown an increasing trend, touching IDR. 60,000 per $\mathrm{kg}$, previously IDR.30,000 per kg, (Media Indonesia, February 10, 2020 edition). Compared to the same period the previous year (February 2019) the price was still around IDR 43,292 per kg. Garlic price movements that are very volatile and often uncontrolled are followed by a decrease in people's purchasing power, followed by an increased inflation rate due to rising prices for goods, making the people's economy sluggish. So that the study of volatility and trend of price movements will provide useful information about / on parties to make policy. The price volatility studies / studied conducted by Shiferaw (2012) analyzed the prices of the nuts and oil group of Ethiopia; Viana, et al (2017), on the commodity of red chilies_and chili peppers in West Java. Studies on spillover volatility have been carried out by Rapsomanikis and Mugera, (2011) in the world and domestic food markets in Ethiopia; Zhao and Goodwin (2011); and Rapsomanikis, (2011). Generally in this study, they used the ARCH / GARCH method. The results of the most recent study published by Vartanian, (2020), on the effect of volatility in commodity price transmission and Bovespa in Brazil, using the multivariate ARCH / GARCH model. Then by Barbaglia, et al (2020), regarding the spillover volatility of market commodities (including agricultural commodities and biofuel energy using the t-Vector Autoregression (VAR) approach. The conclusions of their study show that there is an impact on the spillover situation between energy and biofuels; and between energy and agricultural commodities.

This study was to measure the volatility and volatility of spillover garlic in the traditional markets of East Nusa Tenggara Province (NTTT) as well as the trend of price movements before and during the Covid-19 pandemic period. This study will provide important information about/on decision making in facing the price crisis and policy making in garlic trading.

\section{METHODS OF RESEARCH}

This study uses a historical volatility approach from / to monthly garlic price time series data, for the period July 2016-April 2020 at the NTT market location. The location of the province of NTT is known as an archipelago province that is always deficient in garlic need. So it needs to be supplied from to NTT. The NTT region as an archipelago province that always gets garlic supplies from to NTT, makes it vulnerable to disparities and price fluctuations of regions if supply is disrupted. This study analyses price volatility and spillover volatility between markets in Kupang City (Kupang) and markets in Maumere City (Maumere). Kupang is on the island of Timor and Maumere on the island of Flores, the two largest islands in NTT. Analysis of price volatility uses the ARCH / GARCH method, and measures the volatility of spillovers using the GARCH-multivariate model, namely the GARCH-BEKK model. To test the volatility and volatility of the spillover used time series data onto several test stages, namely: Data stationary test. Stationarity tests uses ADF or Augmented Dickey-Fuller (Enders, 1995; Widarjono (2018); Ekananda, 2016 and Nendissa et al, 2018). This test aims to avoid Spurious regression. This test is to solve problems such as those raised by Chen, and Tu, 2019; Phillips et al, 2019; Enns et al, 2016). The ADF test is formulated:

$$
\Delta \mathrm{P}_{\mathrm{t}}=\mathrm{a}_{0}+\mathrm{V}_{1} \mathrm{P}_{\mathrm{t}-1}+\beta_{\mathrm{I}} \sum_{\mathrm{I}=1}^{\mathrm{m}} \Delta \mathrm{P}_{\mathrm{t}-1}+\varepsilon_{\mathrm{it}}
$$


Where:

- $\mathrm{P}_{\mathrm{t}}=$ Garlic prices in every market in the period $t(\mathrm{Rp} / \mathrm{kg})$;

- $\mathrm{P}_{\mathrm{t}-1}=$ Garlic prices in each market in period $\mathrm{t}$, before $(\mathrm{Rp} / \mathrm{Kg})$;

- $\Delta \mathrm{P}_{\mathrm{t}}=\mathrm{P}_{\mathrm{t}}-\mathrm{P}_{\mathrm{t}-1}$

- $\Delta \mathrm{P}_{\mathrm{t}-1}=\mathrm{P}_{\mathrm{t}-1}-\Delta \mathrm{P}_{(\mathrm{t}-1)-1}$;

- $\mathrm{m}=$ amount of lag;

- $\alpha \_0=$ intercept;

- $\alpha, \beta, \gamma=$ Parameter coefficient;

- $\varepsilon_{-} \mathrm{t}=$ Error term.

Hypothesis test:

- $\mathrm{H}_{0}: \mathrm{Y}=0$ time series data is not stationary;

- $\mathrm{H}_{1}: \mathrm{\gamma}<0$ stationary time series data.

Test for the presence of ARCH (ARCH Effect). This test uses the Lagrange Multiplier test (ARCH-LM-test), using the EViews 9 program tool. Then the GARCH model is continued as explained by Ekananda (2016). Spillover volatility analysis uses the GARCH-BEKK model to reveal spillovers between market prices in Kupang and Maumere, measured whether there are spillover transmissions of markets. Then a model of garlic price volatility was developed among markets in NTT. After finding the model, we continue to measure the volatility of the spillover between traditional and modern markets. This analysis model is carried out with the help of the Eviews program application. Trend in price movements. Analysis of the trend behaviour of monthly prices / priced movements towards / away graphical analysis. The observation time period is from July 2016-April 2020. The movement away price behaviour entering the Covid-19 pandemic uses data onto January to April 2020, monthly price data and weekly prices. To measure the level of price fluctuation using the Coefficient of Variation (CV) analysis with the criteria the higher the CV value the more fluctuating. The Indonesian Ministry of Trade uses a standard of $0-5 \%$ low fluctuation, $5-9 \%$ moderate fluctuation, while $>9 \%$ high fluctuation to very high, the Ministry of Trade of the Republic of Indonesia 2014 and Nendissa et al 2018).

Measure the coefficient of variation (CV) is:

$$
\mathrm{CV}=\frac{\mathrm{SD}}{x} \times 100 \%
$$

Formula standard deviation (SD) is:

$$
\mathrm{SD}=\sqrt{ } \frac{\Sigma(X-x)^{2}}{n} .
$$

Where:

- $\mathrm{SD}=$ Standard Deviation;

- $\mathrm{X}=$ Price changes;

- $x=$ Average change in price;

- $\mathrm{n}=$ total average price.

\section{RESULTS AND DISCUSSION}

Prior to the volatility analysis, it went through several test stages, considering that time series data are generally not stationary, including: Data stationary test. This stationary test is used ADF with intercepting and trend models and finds the data is not stationary, and it is found that the data is stationary in the first difference (orde 1) where the data does not contain a unit-roots so that if regression does not cause spurious regression. Test for the presence of $\mathrm{ARCH}$ (ARCH Effect). The results using the ARCH test of the Kupang garlic price have significant results because the probability is $<10 \%(0.0899161<0.1)$ with the probability coefficient value $(\alpha 0)$ of 0.0004 or real at the $95 \%$ confidence level, while the probability of prices is at the residual square level at the previous period ( $\alpha 1$ ) was 0.0908 or 
real at a $90 \%$ level of confidence, meaning that it accepted $\mathrm{H} 1$ and rejected $\mathrm{H} 0$. This indicates that the garlic priced variable in Kupang contains an $\mathrm{ARCH}$ effect on a $90 \%$ confidence level. Furthermore, the ARCH test results from garlic prices in Maumere have significant results because the probability is smaller than $10 \%(0.0765933<0.1)$ with a probability coefficient value $(\alpha 0)$ of $1.74 \mathrm{e}-05$ or real at the $95 \%$ confidence level, while the probability of the price at the residual square level in the previous period ( $\alpha 1$ ) was 0.0773 or real at the $90 \%$ confidence level, meaning that $\mathrm{H} 1$ accepted and rejected $\mathrm{H} 0$. This indicates that the garlic a priced variable in Maumere City contains an $\mathrm{ARCH}$ effect of/on a $90 \%$ confidence level.

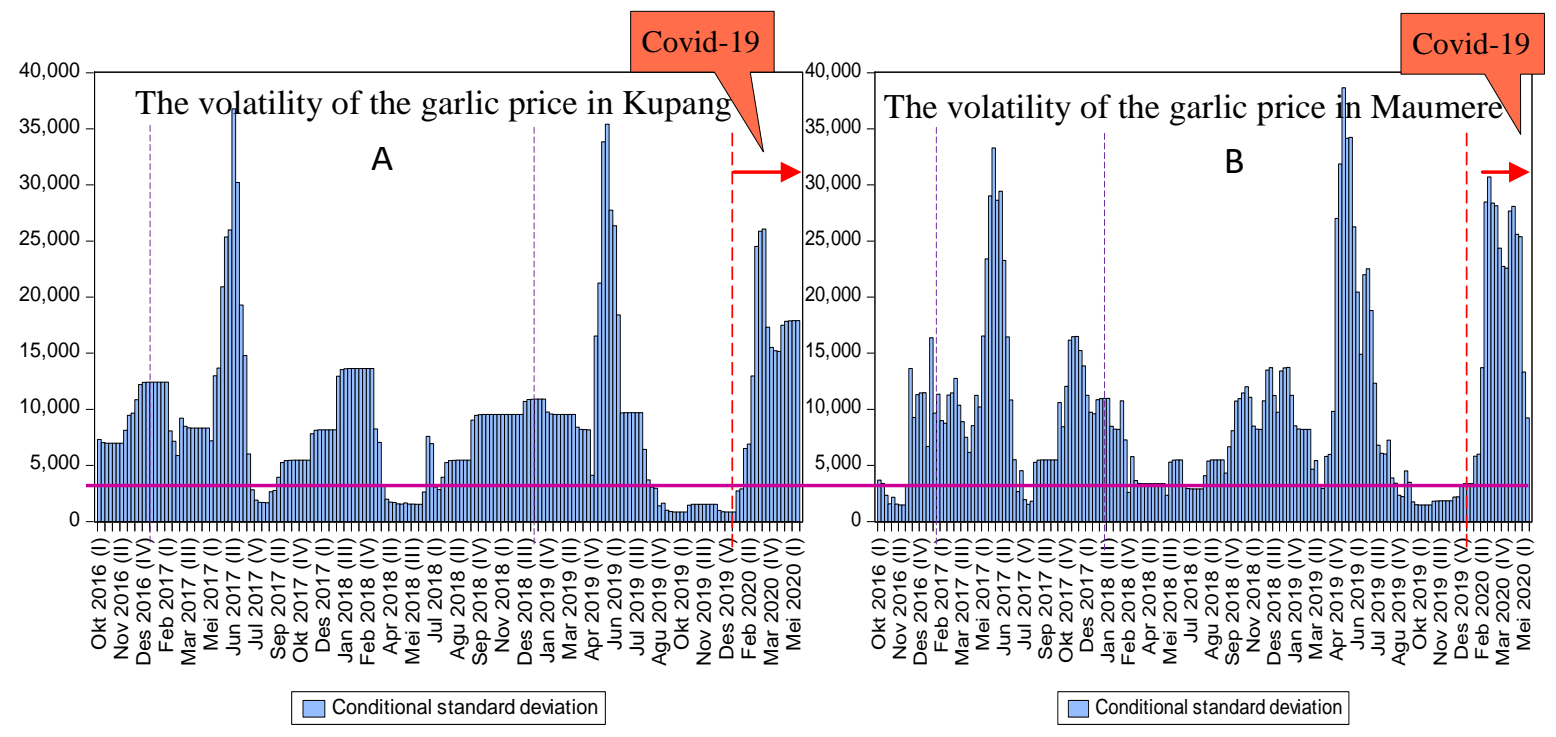

Figure 1 - Trends in the Volatility of Garlic Prices in Kupang and Maumere

(Secondary data, 2020, processed)

Figure 1 shows that the trend of garlic prices in Maumere is more volatile than prices in Kupang. The aspects of transportation, marketing infrastructure, and marketing information networks are the determining factors of volatility in these two areas. The marketing infrastructure and trade distribution of Kupang is relatively better than in Maumere, which affects the flow of this commodity. So that the balance of supply and demand garlic in Kupang is more balanced compared to Maumere. Observing the effects of price volatility during the Covid-19 period from February to May 2020, It has not shown volatile price fluctuations. The trend of increasing prices only occurs when the social distance is applied, then panic baying to occur, economic activity, restaurants, hotels, off-work offices, and disturbed logistics flow. Volatility analysis. Volatility can be determined by looking at the $\alpha+\beta$ value (Piot-Lepetit, 2011). In this case, $\alpha$ is the ARCH value while $\beta$ is the GARCH value. As explained by Piot-Lepetit (2011), the volatility is known by $\alpha+\beta$ from the GARCH model equation. If $\alpha+\beta=1$ high volatility category; $\alpha+\beta>1$ is in the category of explosive volatility (extreme volatility), whereas if $\alpha+\beta<1$ is in the low volatility category. This volatility analysis does not directly use the value of $\alpha+\beta$ because it is also determined by the probability that determines the value is real or not. Analysis of volatility on garlic prices in Kupang, using the $\mathrm{ARCH}$ model, obtained the $\mathrm{ARCH}$ equation, with the formula:

$$
\sigma_{t}^{2}=9788020+0,133702 \varepsilon_{\text {KUPANG }_{t-1}}^{2}
$$

From these results, it shows that garlic prices in Kupang show low volatility, as indicated by the estimated coefficient $\alpha i+\beta j<1$. By looking at the results of price volatility with the GARCH model, the GARCH equation is obtained, which is as follows:

$$
\sigma_{t}^{2}=945509+0,361506 \varepsilon_{\text {KUPANG }_{t-1}}^{2}+0,638494 \sigma_{\text {KUPANG }_{t-1}}^{2}
$$


From these results indicate that the number of estimation coefficients $\alpha i+\beta j=1$, which means that the volatility of garlic prices in Kupang is moderate. Furthermore, analysis of the volatility of garlic prices in Maumere, the ARCH equation is obtained:

$$
\sigma_{t}^{2}=9874310+0,129834 \varepsilon_{\text {MAUMERE }_{t-1}^{2}}
$$

This shows that the price of garlic in Maumere shows low volatility, referring to the estimated coefficient $\alpha i+\beta j<1(0.129834)$, . Based on the results of price volatility with the $\mathrm{GARCH}$ model, the following equation is obtained:

$$
\sigma_{t}^{2}=1895300+0,467417 \varepsilon_{\text {MAUMERE }_{t-1}^{2}}^{2}+0,498064 \sigma_{\text {MAUMERE }}^{2}
$$

From these results indicate that the total estimated coefficient of $\alpha i+\beta j<1$ (0.965481), which means that the volatility of garlic prices in Maumere is low volatility.

The results of the spillover volatility analysis using the EGARCH model, the following equation is obtained:

$$
\ln \left(\sigma_{t}^{2}\right)=1,03955+0,92586^{\star} \ln \left(\sigma_{t-1}^{2}\right)+0,16012\left(\left|\frac{\varepsilon_{t-1}}{\sigma_{t-1}}\right|-\sqrt{\frac{2}{\pi}}\right)+0,57233 \frac{\varepsilon_{t-1}}{\sigma_{t-1}}
$$

These results indicate that the estimated coefficient yi is close to $<1$ (0.57233), It means that the spillover volatility or the effect of price volatility in Maumere on prices in Kupang does not have an asymmetric effect. When there is a positive shock (ct $\geq 0)$, the change in volatility is $\mathrm{yi}+$ ai $(0.73245)$. Meanwhile, when there is a negative shock $(\varepsilon t<0)$, the change in volatility is $\mathrm{yi}-$ ai $(0.41221)$. This shows that the change in volatility resulting from a positive shock is greater than a negative shock. If a positive shock increases volatility more than a negative shock, then yi indicates no asymmetric effect on volatility. The effect of the volatility of garlic prices in Maumere on the volatility of garlic prices in Kupang shows that there is no asymmetric effect on volatility, where a positive shock increases volatility more than a negative shock. This explains that the high volatility of garlic prices in Maumere City affects the volatility of garlic prices in Kupang City which is also high volatility. The volatility of garlic prices in Kupang and the volatility of garlic prices in Maumere both experienced a positive shock (prices tend to be low) which further increased the volatility. So, it can be concluded that there is spillover garlic volatility in NTT, where the volatility of garlic prices in Maumere City affects the volatility of garlic prices in Kupang City.

Figures 2 and 3 illustrate the monthly price trend and weekly price trend during the period July 2016 - April 2020.

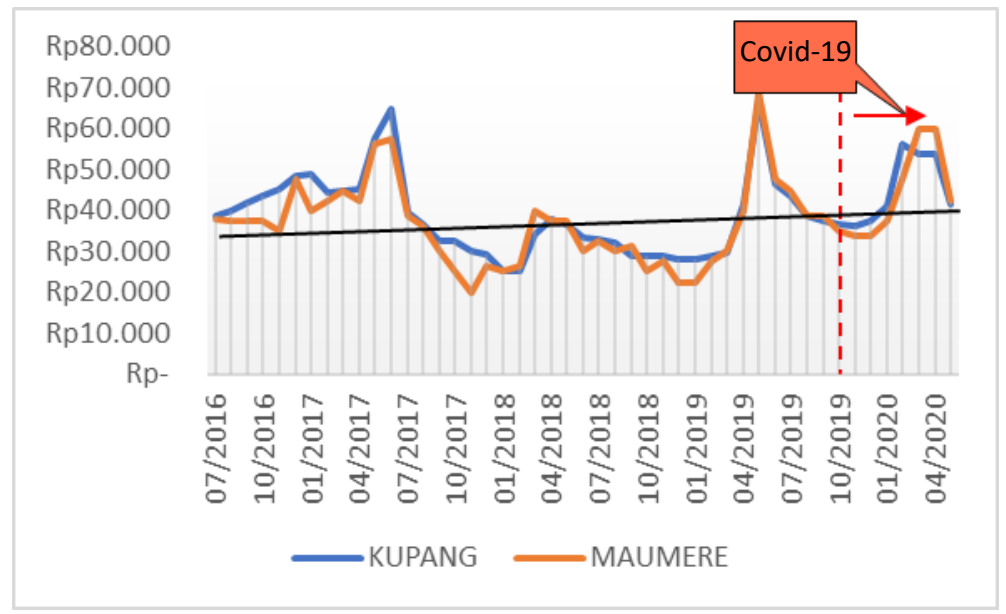

Figure 2 - Monthly Garlic Price Movements in Kupang and Maumere (Secondary data, 2020, processed) 
The trend of garlic prices in Kupang and Maumere has a very slight tendency to increase; this can be seen from the data plot of Figures 2 and 3, where from month to month and week to week the trend of garlic prices has a weak increase. The price trend includes an uptrend line that has a positive slope.

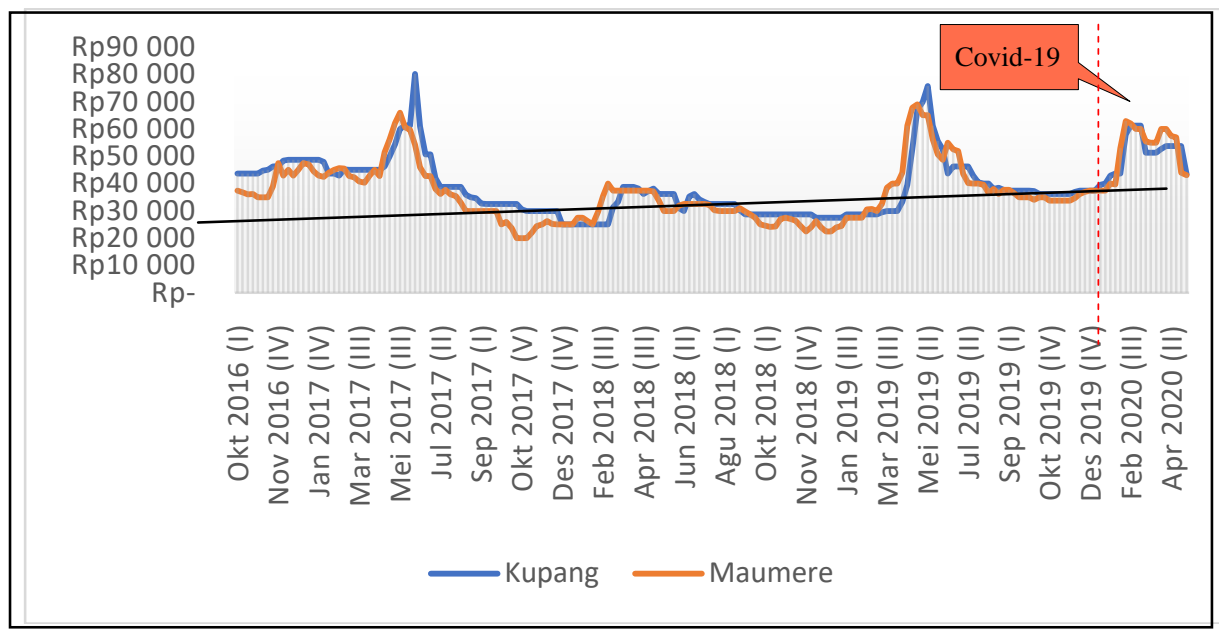

Figure 3 - The pattern of price movements towards / away both markets

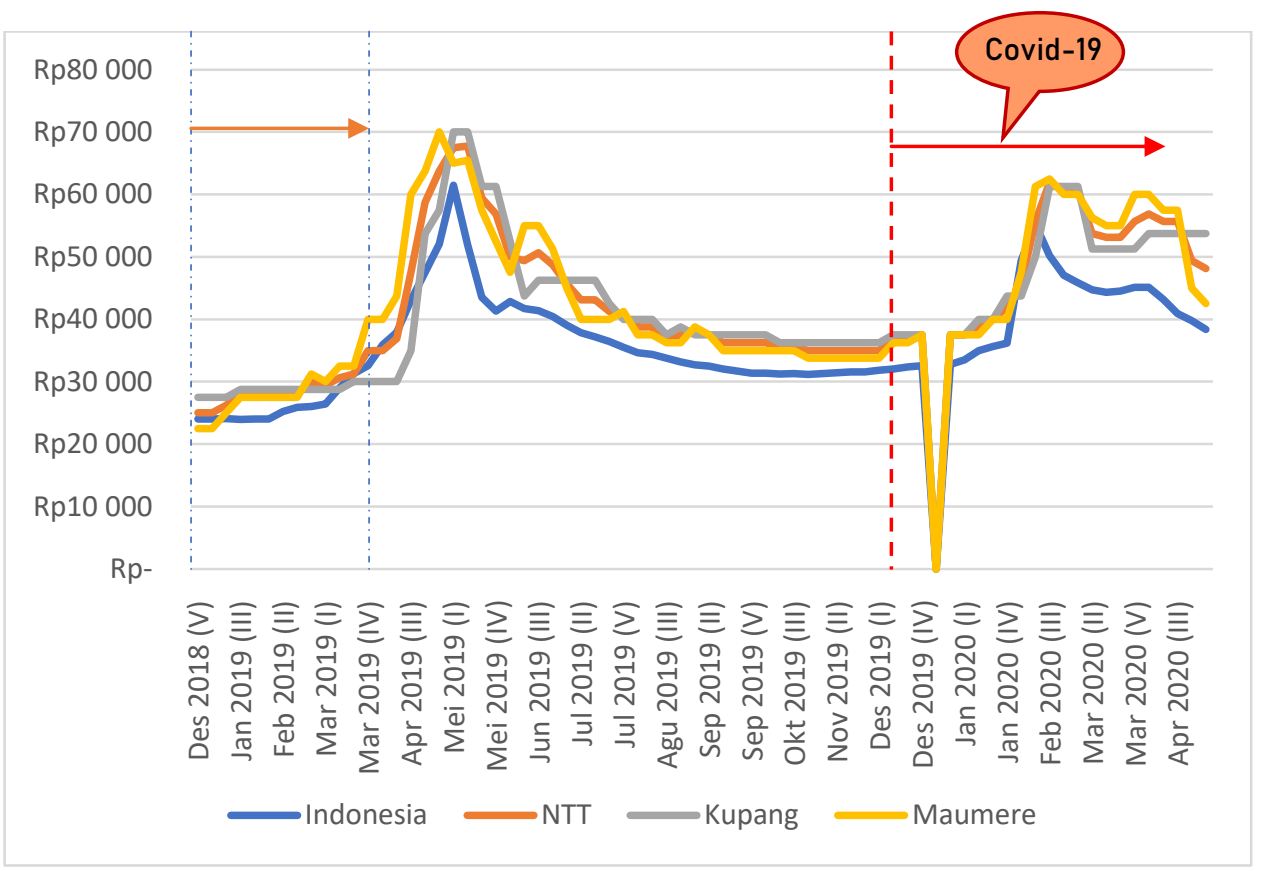

Figure 4 - Trends in garlic prices before and during the Covid-19 pandemic in Indonesia, NTT, Kupang and Maumere, the 2019-April 2020 period

Figure 4 explains that in the Covid-19 pandemic, the price volatility of garlic was not too large when compared to the same period in 2019. The price increase occurred in early February 2020 and continued to rise until March 2020 then continued to decline until April 2020. This condition happened almost evenly to Kupang NTT and Indonesia in general. This can be seen from the pattern of price movements away Figure 4. This proves that the Covid19 pandemic period is currently suppressing supply and demand simultaneously. Due to decreased consumption and purchasing power as well as blocked distribution channels due to social distance. Meanwhile, domestic garlic stocks are still sufficient for the next few months. There is a chance of a supply crisis and price fluctuations if garlic stocks decline and imports are still hampered by the import and export restriction policies in exporting countries 
to maintain domestic needs The same picture also occurs to commodity shallots in Kupang and Surabaya (Nendissa et al, 2020 ).

Based on the CV value obtained on the prices of garlic in Kupang and Maumere, it fluctuates greatly, namely CV of $26.032 \%$ and $29.626 \%$ based on indicators from the Indonesian Ministry of Trade. The results of the Kapioru et al. 2020 study show that the prices of shallots in Kupang and Surabaya fluctuate high in the adjacent period. Large price fluctuations of regions are thought to be due to differences in marketing infrastructure and NTT is an archipelago so that the transportation network is the main determinant of the distribution of trade commodities between regions, in addition to other factors(Blein, and Longo, 2009 put forward the same reason; Jacks et al, 2011; Hamulczuk et al, 2019; Nendissa et al, 2020 and Kapioru et al, 2020).

\section{CONCLUSION}

The volatility of garlic prices in Kupang and Maumere shows a relatively weak trend of movement. Between the two cities, the price volatility trend in Maumere is higher than Kupang. Entering the Covid-19 pandemic period, price movements away NTT did not show any volatility (not volatile). The conditions of trade infrastructure, transportation networks and information are thought to be the cause of this difference. The condition of the province of NTT as an archipelago contributes to price disparities between regions. Price movements away both regions exhibit the same pattern with a very sluggish uptrend. Entering the Covid19 pandemic period, prices rose at the beginning of the period then fell and returned to stability. The increase in the beginning of the period was due to panic buying. Monitoring price movements and maintaining a balance between supply and demand are the concern of policy makers and market players.

\section{ACKNOWLEDGMENTS}

Thanks to the Department of Agribusiness and the Faculty of Agriculture, University of Nusa Cendana for their support in presenting this paper.

\section{REFERENCES}

1. Akhter, S. (2017). Market Integration between Surplus and Deficit Rice Markets During Global Food Crisis Period. Australian Journal of Agricultural and resource economics, 61(1), 172-188.

2. Amalo, P. (2019). Harga Garlic di Kupang Tembus Rp90 Ribu per Kg. Media Indonesia. Nusantara. Selasa, 14 Mei 2019. https://mediaindonesia.com/read/detail/235448-hargabawang-putih-di-kupang-tembus-rp90-ribu-per-kg. Diunduh 10 Maret 2020.

3. Media Indonesia, (edisi 10 Febeuari 2020). Efek Virus Korona, Harga Garlic di Kupang Rp60 Ribu per Kg. Mediaindonesia.com. https://mediaindonesia.com/read/detail/289056efek-virus-korona-harga-bawang-putih-di-kupang-rp60-ribu-per-kg. Diunduh 11 Maret 2020.

Anindita, R. (2008). Pendekatan Ekonomi untuk Analisis Harga; Cetakan Pertama; Penerbit KENCANA Prenada Media Grup, Jakarta Indonesia.

4. Anindita, R and Baladina, N. (2017). Pemasaran Produk Pertanian; Penerbit Andi; Yogyakarta. Indonesia.

5. Barbaglia, L., Croux, C., \& Wilms, I. (2020). Volatility spillovers in commodity markets: A large t-vector autoregressive approach. Energy Economics, 85, 104555.

6. Blein, R., \& Longo, R. (2009). Food price volatility-how to help smallholder farmers manage risk and uncertainty. Round Table organized during the Thirty-second session of IFAD's Governing Council.

7. Barrera, A. T; Mindy, M; and Philip, G. (2012). Vollatiliti Spillover in U.S. Crue Oil, Ethanol, and Corn Future Market. Agricultural Economics Association 32(2); 246-262. Western Agricultural Economics Association. 
8. Belshaw, Cyril S. 1981. Tukar-Menukar Tradisional and Pasar Modern. Jakarta.

9. Bollerslev, T. (1986). Generalized Autoregressiv Conditional Heterokesdastisity, Journal of Ekonometrics; 31:307-327.

10. Buguk, C; Hanson, D and Hanson, T. (2003). Price Volatility Spillover In Agricultural Market: An Examination of U.S. Caffis Markes: Journal of Agricultural and Resouce Economics 28(1): 86-8=99. Gaziosmanpasa University. Turkey.

11. Caldara, D., Cavallo, M., \& lacoviello, M. (2019). Oil price elasticities and oil price fluctuations. Journal of Monetary Economics, 103, 1-20.

12. Chevallier, J., \& Ielpo, F. (2013). Volatility spillovers in commodity markets. Applied Economics Letters, 20(13), 1211-1227.

13. Clem, A, (1985). Commodity price volatility: trends during 1975-84. Monthly Labor Review, 108, 17.

14. Chen, Y., \& Tu, Y. (2019). Is stock price correlated with oil price? Spurious regressions with moderately explosive processes. Oxford Bulletin of Economics and Statistics, 81(5), 1012-1044.

15. Christanty, H and Ari, W. S. (2012). Pengaruh Volatilitas Harga Terhadap Inflasi di Kota Malang; Pendekatan ARCH/GARCH. Fakultas IImu Ekonomi and Bisnis; Universitas Brawijaya. Malang; Jawa Timur.

16. Damayanti, E. (2008) Kebijakan Initial Margin and Volatilitas harga pada Perdagangan Berjangka Komoditas Olein di Indonesia, Fakultas Ekonomi Universitas Indonesia, Jakarta.

17. Ekananda, M. 2016. Ekonometrika Dasar untuk Penelitian Bidang Ekonomi Sosial and Bisnis.

18. Enders, W. 1995. Applied Applied Econommetric Time Series., New York: Jonh Wiley\&Sons. Inc. Göktaş, Ö.(2005) Teorik ve Uygulamalı Zaman Serileri Analizi, İstanbul: Beşir Kitabevi

19. Engel, R. F. (1982). Autoregressiv Conditional Heterokedastisity with Estimate of the Vatiance of UK Inflatio. Econometrika 50: 987-1008.

20. Enns, P. K., Kelly, N. J., Masaki, T., \& Wohlfarth, P. C. (2016). Don't jettison the general error correction model just yet: A practical guide to avoiding spurious regression with the GECM. Research \& Politics, 3(2), 2053168016643345.

21. Fajrian, H, (Ed). 2020. Impor Terhambat Dampak Corona, Pengusaha Indikasikan Harga Pangan Naik. Katadata.co.id. https://katadata.co.id/berita/2020/03/12/impor-terhambatdampak-corona-pengusaha-indikasikan-harga-pangan-naik. Diunduh 10 Maret 2010.

22. Fardaniah, R. (Ed). (2019). Harga garlic di Kupang tembus Rp70.000/ kilogram. Antaranews.com. https://www.antaranews.com/berita/855573/harga-bawang-putih-dikupang-tembus-rp70000-kilogram. Diunduh 11 Maret 2020.

23. Fiansyah, R (Ed). (2020). Mentan Sebut Harga Garlic Melonjak Gara-Gara Panik Isu Virus Korona. Antara, Kamis, 13 Februari 2020. https://www.inews.id/finance/makro/mentan-sebut-harga-bawang-putih-melonjak-garagara-panik-isu-virus-korona. Diunduh 9 Maret 2020.

24. FAO, I. WFP. (2014). The State of Food Insecurity in the World: Strengthening the Enabling Environment for Food Security and Nutrition. Food and Agriculture Organization of the United Nations: Rome.

25. Food And Agriculture Organization Of The United Nations, (2015). The state of food insecurity in the world 2014: strengthening the enabling enviroment for food... security and nutrition. Food \& Agriculture Org.

26. Geiger, M., \& Scharler, J. (2019). How do consumers assess the macroeconomic effects of oil price fluctuations? Evidence from US survey data. Journal of Macroeconomics, 62, 103134.

27. Gilbert, C. L; and Morgan, C. W. (2010). Food Price Volatility. Philosophical Transactions of the Royal Society B: Biological Sciences, 365(1554), 3023-3034.

28. Hamulczuk, M., Makarchuk, O., \& Sica, E. (2019). Price Behaviour and Market Integration: Preliminary Evidence from the Ukrainian and European Union Rapeseed 
Markets. Problems of World Agriculture / Problemy Rolnictwa Światowego, 19 (18272019-1869), 47-58.

29. Jacks, D. S., O'Rourke, K. H., \& Williamson, J. G. (2011). Commodity price volatility and world market integration since 1700. Review of Economics and Statistics, 93(3), 800-813.

30. Kalkuh, M; Lukas, K; Marta, K; Pierre, N and Maximo, T. (2013). Conceptual Framwork on Price Volatility and His Impect to Food and Nutrion Security in the Short Time. Foodsecure working paper No.15. Interdisciplinary Research Project to Explore the Future of Global Food and Nutrion Security.

31. Kapioru, Ch., Bano, M., \& Nendissa, D. R. (2020). Market Cointegration and Red Chili Price Behavior Between Wholesalers and Traditional Markets, RJOAS, 8(104), August 2020; DOI 10.18551/rjoas.2020-08.20.

32. Khan, N; and Faisal, S. (2020). Epidemiology of Corona Virus in the World and Its Effects on the China Economy. Available at SSRN 3548292.

33. Khan, N; Fahad, S; Faisal, S; and Naushad, M. (2020). Quarantine Role in the Control of Corona Virus in the World and Its Impact on the World Economy. SSRN 3556940.

34. Kementerian Perdagangan, 2014. Outlook Pangan Tahun 2015-2019, Laporan Ringkas. Pusat Kebijakan Perdagangan Dalam Negeri, Badan Pengkajian and Pengembangan Kebijakan, Kemendag.

35. Media Indonesia (2020). Efek Virus Korona, Harga Garlic di Kupang Rp60 Ribu per Kg. Mediaindonesia.com. https://mediaindonesia.com/read/detail/289056-efek-virus-koronaharga-bawang-putih-di-kupang-rp60-ribu-per-kg. Diunduh 11 Maret 2020.

36. Mortazavi, S. M., Maleki, A., \& Yousefi, H. (2019). Analysis of robustness of the Chinese economy and energy supply/demand fluctuations. International Journal of Low-Carbon Technologies, 14(2), 147-159.

37. Nendissa D. R; Anindita R; Hanani N; \& Muhaimin A. W. (2018). Beef Market Integration in East Nusa Tenggara of Indonesia. RJOAS: Russian journal of Agricultural and SocioEconomic Sciences 8(80). August 2018. DOI: 10.18551/rjoas.2018-08.51.

38. Nendissa, D. R., Olviana., T \& Kapioru, Ch. (2020) The Impact of the Covid-19 Pandemic on Price Disparities and Fluctuations of Shallots in Traditional Markets; RJOAS, 7(103), July 2020. DOI 10.18551/rjoas.2020-07.14.

39. Piot-Lepetit, I. (2011). Price volatility and price leadership in the EU beef and pork meat market. In Methods to analyse agricultural commodity price volatility (pp. 85-105). Springer, New York, NY.

40. Rapsomanikis, G. (2011). Price Transmission and Volatility Spillovers in Food Markets. Safeguarding food Security in Volatile Global Markets, 149-168.

41. Rapsomanikis, G; and Mugera, H. (2011). Price Transmission and Volatility Spillovers in Food Markets of Developing Countries. In Methods to Analyse Agricultural Commodity Price Volatility (pp. 165-179). Springer, New York, NY.

42. Shiferaw, Y. (2012). Modeling Price Volatility for Some Selected Agricultural Products in Ethiopia: ARIMA-GARCH Applications. Available at SSRN 2125712.

43. Tothova, M. (2011). Main Challenges of Price Volatility in Agricultural Commodity Markets. In Methods to Analyse Agricultural Commodity Price Volatility (pp. 13-29). Springer, New York, NY.

44. Vartanian, P. R. (2020). Volatility Transmission Between Commodities and Ibovespa in the Period 2000-2016: Is There a Possibility of Diversification? International Economics and Economic Policy, 1-19.

45. Viana, C. D, N; Hartono, S; and Wuluyaril, L. R. (2017). Volatility Analysis on Producer Price of Red Pepper and Cayenne Pepper in West Java Province Indonesia. Agro Ekonomi Vol. 28/No. 2, Desember 2017.

46. Widarjono, 2018. Ekonometrika: Pengantar and Aplikasinya Disertai Panduan Eviews UPP STIM YKPN, Yogyakarta.

47. Zhao; Jieyuan; and Goodwin, (2011). Volatility Spillovers in Agricultural Commodity Markets: An Application Involving Implied Volatilities from Opions Market. Selection Paper Prepared for Presentation at the Agricultural and Applied Economics Association's 2011 AAEA \& NEREA Joint Annual Meeting Pittsburgh, Pennsylvania. 